\title{
Oral administration of vanadate to diabetic rats restores liver 6-phosphofructo-2-kinase content and mRNA
}

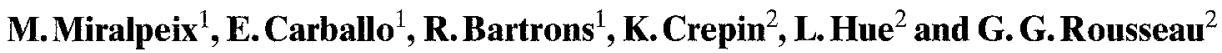 \\ 1 Unitat de Bioquímica, Departament de Ciències Fisiològiques, Universitat de Barcelona, Zona Universitària Bellvitge, Spain, \\ ${ }^{2}$ Hormone and Metabolic Research Unit, University of Louvain Medical School, and International Institute of Cellular and Molecular \\ Pathology, Brussels, Belgium
}

\begin{abstract}
Summary. Vanadate and insulin were administered to diabetic (streptozotocin) rats to compare their effects on the activity and mRNA content of 6-phosphofructo-2-kinase and L-type pyruvate kinase in the liver. The activity of 6-phosphofructo-2-kinase in livers of diabetic rats was about $40 \%$ of that found in normal rats. A similar decrease was found for 6-phosphofructo-2-kinase/fructose-2,6-bisphosphatase content, measured by immunoprecipitation, and for mRNA, measured by hybridization of Northern blots. Administration of vanadate to the diabetic rats led to a progressive recovery of 6-phosphofructo-2-kinase activity, and 6-phosphofructo-2-kinase/fructose-2,6-bisphosphatase content and mRNA. This recovery, which was complete after 15 days of
\end{abstract}

oral treatment, was also obtained after $60 \mathrm{~h}$ of insulin administration. L-type pyruvate kinase activity and mRNA were also decreased by about $70 \%$ in livers of diabetic rats. Both parameters normalized after 15 days of vanadate treatment, whereas insulin administration $(60 \mathrm{~h})$ raised L-pyruvate kinase mRNA three-fold above control values. Oral treatment for 15 days with vanadate can thus mimic the effect of insulin on both pyruvate kinase and 6-phosphofructo-2-kinase/fructose-2,6-bisphosphatase in livers of diabetic rats.

Key words: 6-phosphofructo-2-kinase mRNA, L-type pyruvate kinase mRNA, vanadate, diabetes, liver.
Vanadium compounds mimic most of the actions of insulin in intact cells [1-7] and in the whole animal [8-12]. One of the most interesting "in vivo" effects of vanadate is its ability to normalize the high blood glucose of rats with streptozotocin-induced diabetes [8-10]. In these animals, vanadate does not increase serum insulin levels [8], suggesting that insulin target tissues themselves are the site of vanadate action. Furthermore, the oral administration of vanadate leads to normoglycaemia by stimulating glucose uptake in liver and muscle [9]. In skeletal muscle [11] and liver [12], vanadate reverses the defect in glycogen synthesis of diabetic animals, and does not modify the insulin binding characteristics $[13,14]$.

In a previous paper [10], we demonstrated that additional effects of vanadate on hepatic carbohydrate metabolism could also be involved in the reduction of plasma glucose concentration after its oral administration to diabetic rats. Vanadate normalized glucokinase activity, which was almost absent in the liver of diabetic animals. The increase in glucokinase activity was due to an increase in its mRNA [15] and was correlated with the increase in glucose uptake [9]. Furthermore, vanadate activated hepatic glucose consumption through an increase in fructose 2,6-bisphosphate (Fru-2,6-P $\mathrm{P}_{2}$ ) and 6-phosphofructo-2-ki- nase (PFK-2) activity $[10,16]$. Fru-2,6- $\mathrm{P}_{2}$ is indeed a potent stimulator of glycolysis and inhibitor of gluconeogenesis in liver [17-19]. The concentration of Fru-2,6- $\mathrm{P}_{2} \mathrm{de}-$ pends on the balance between the activities of PFK-2 and fructose 2,6-bisphosphatase (FBPase-2), which respectively catalyses its synthesis and breakdown [17-19]. It has been reported that the mRNA level for liver PFK-2/ FBPase-2 does not decrease in starvation or diabetes despite a decrease in PFK-2 enzyme content [20, 21]. However, it has also been shown that feeding after starvation or insulin administration to diabetic rats causes co-ordinate increases in the liver bifunctional enzyme and its mRNA [21]. The aim of the present work was to study the effect of oral vanadate administration to diabetic rats on liver PFK-2 activity, and on PFK-2/FBPase- 2 content and mRNA levels. We also determined the activity and the mRNA level of hepatic L-type pyruvate kinase (L-PK).

\section{Materials and methods}

\section{Chemicals}

All reagents were of the best grade commercially available. $\left[\alpha^{32} \mathrm{P}\right] \mathrm{dCTP}(3000 \mathrm{Ci} / \mathrm{mmol})$, multiprime DNA labelling system, and nylon membranes were from Amersham International plc 
(Amersham, Bucks, UK). Nitrocellulose membranes were from Schleicher \& Schuell (Dassel, FRG). Protein A Sepharose CL-4B was from Pharmacia (Uppsala, Sweden). RNA ladder was from Bethesda Research Laboratories (Gaithersburg, Md, USA). Sodium orthovanadate $\left(\mathrm{Na}_{3} \mathrm{VO}_{4}\right)$ and streptozotocin were from Sigma (St.Louis, Mo., USA).

\section{Animals}

Male Sprague-Dawley rats weighing 200-250 g were used. Diabetes was induced by a single intravenous injection of streptozotocin $(60 \mathrm{mg} / \mathrm{kg})$ dissolved in $0.5 \mathrm{ml}$ of $50 \mathrm{mmol} / \mathrm{l}$ sodium citrate, $0.15 \mathrm{~mol} / 1 \mathrm{NaCl}, \mathrm{pH} 4.5$. Control rats received the buffer only. One week later, blood samples were collected from the tail vein for glucose determination. Animals whose glycaemia exceeded $19 \mathrm{mmol} / \mathrm{l}$ were considered to be diabetic. Streptozotocin-injected animals treated with vanadate were given water containing $\mathrm{NaCl}$ $(0.5 \mathrm{~g} / 100 \mathrm{ml})$ and sodium orthovanadate $(70 \mathrm{mg} / 100 \mathrm{ml})$, prepared freshly everyday. The control groups of animals were given a $0.5 \mathrm{~g} / 100 \mathrm{ml} \mathrm{NaCl}$ solution. Diabetes was assessed periodically by testing for glucosuria (Urotron; Boehringer, Mannheim, FRG). Diabetic rats treated with insulin (Actrapid; Novo Industri, Copenhagen, Denmark) received $30 \mathrm{IU} / \mathrm{kg}$ subcutaneously at 8-h intervals over $60 \mathrm{~h}$. Animals were killed by decapitation 1-2 h after the last insulin dose. Blood samples were collected at the time of death, and the livers were freeze-clamped in liquid nitrogen and stored at $-70^{\circ} \mathrm{C}$ prior to extraction.

\section{Assays of enzymes and metabolites}

PFK-2 activity was measured as described [22], using the assay at $\mathrm{pH} 8.5$ which yields the "total" activity and which is not affected by the phosphorylation state of the enzyme [22]. Total L-PK activity was measured at $5 \mathrm{mmol} / \mathrm{l}$ phosphoenolpyruvate as described [23]. One unit of enzyme activity corresponds to $1 \mu \mathrm{mol}$ of substrate used per min, under the conditions of the assay. Blood glucose was assayed as described [24]. Protein was determined according to Bradford [25], with bovine serum albumin as a standard.

\section{Immunotitration of liver PFK-2/FBPase-2}

To obtain liver cytosol, samples were homogenized (Potter-Elvejhem homogenizer) in 3 volumes of an ice-cold solution containing $50 \mathrm{mmol} / 1 \mathrm{KCl}, 2 \mathrm{mmol} / 1 \mathrm{EDTA}, 5 \mathrm{mmol} / 1 \mathrm{MgCl}, 15 \mathrm{mmol} / 1$ $\beta$-mercaptoethanol, $0.1 \mathrm{mmol} / /$ phenylmethylsulphonyl fluoride, leupeptin $(8 \mu \mathrm{g} / \mathrm{ml})$, aprotinin $(16 \mu \mathrm{g} / \mathrm{ml}), 20 \mathrm{mmol} / \mathrm{l}$ Hepes and $1 \mathrm{mmol} / 1$ phosphate, $\mathrm{pH} 7.0$, and centrifuged at $10000 \times \mathrm{g}$ for $20 \mathrm{~min}$ followed by $105000 \times g$ for $60 \mathrm{~min}$ at $4^{\circ} \mathrm{C}$. PFK-2 immunotitration was carried out as described [20]. Briefly, a fixed volume of cytosol $(1.5 \mathrm{mg}$ cytosol protein/ml) and up to $10 \mu \mathrm{l}$ of the (BCL-2) anti-PFK2 antiserum were incubated in $0.2 \mathrm{ml}$ containing $100 \mathrm{mmol} / \mathrm{K} \mathrm{KCl}$, $15 \mathrm{mmol} / 1 \beta$-mercaptoethanol, $20 \mathrm{mmol} / 1$ Tris, $\mathrm{pH} 8.0,0.1 \%$ bovine serum albumin, $75 \mu \mathrm{l}$ of protein A-Sepharose suspension $(1: 1)$. After $30 \mathrm{~min}$ of agitation at room temperature, the immune complexes were precipitated $\left(8000 \times g, 4 \mathrm{~min}, 4^{\circ} \mathrm{C}\right)$ and the residual PFK-2 activity was measured in the supernatant. The liver PFK-2 content is expressed as the volume of BCL-2 antiserum required to precipitate $50 \%$ of PFK-2 activity in the presence of protein A-Sepharose. It was calculated from the logit plots of immunotitration curves [20].

\section{Determination of $m R N A$ by hybridization}

Total RNA was extracted from livers by a modified [26] guanidium thiocyanate method [27]. The concentration of total RNA was measured by spectrophotometry $\left(\mathrm{A}_{260} / \mathrm{A}_{280}\right)$ and its integrity was systematically verified by electrophoresis in agarose submarine minigels stained with ethidium bromide. Dot blot and Northern blot analyses were performed as described [20, 28]. Filters were hybridized with a 1.4 kilobase $(\mathrm{kb})$ rat liver PFK-2/FBPase-2 cDNA probe (22c1), which corresponds to the mRNA for liver PFK2/FBPase-2 devoid of the $5^{\prime}$ end coding for amino acids 1 to 90 [28]. Chicken $\beta$-actin and rat liver L-PK cDNA probes were used as controls $[20,28]$. cDNA probes were labelled with $\left[\alpha^{32} \mathrm{P}\right] \mathrm{dCTP}$ by the multiprime system. The intensity of hybridization was measured by scanning the autoradiograms using a Chromoscan 3 Joyce Loebl densitometer.

\section{Statistical analysis}

Differences between experimental groups were tested by an analysis of variance (ANOVA) and the appropriate linear contrasts (analysed using Scheffe's critical value, to adjust for multiple comparisons) for the differences vs control or diabetic group. In all tests, a significance level of $p<0.05$ was used.

\section{Results}

To assess the effects of streptozotocin and of oral administration of vanadate, we determined the blood glucose concentration in the different experimental groups of rats. Glycaemia was lowered after vanadate treatment of the diabetic animals, and normalized after 15 days of treatment (Table 1), confirming earlier work [8-10, 12]. We also determined L-PK activity, which is known to decrease in diabetic rats and be restored to normal upon insulin treatment [29], and found this to be the case (Table 1).

We then determined liver PFK-2 activity and PFK2/FBPase-2 content. Consistent with earlier reports [20, 30 , we found that PFK-2 activity in diabetic rats fell to about $40 \%$ of the control values, and that vanadate treatment [10], or insulin administration [30] increased the low hepatic PFK-2 activity of diabetic rats (Table 1 ), but to a different extent and with a different time-course. Insulin treatment for $60 \mathrm{~h}$ raised PFK-2 activity to normal values, whereas the activity was normalized only after 5-7 days of vanadate administration. We also determined by immunotitration (Fig. 1) whether this effect of insulin and vanadate resulted from an increased liver PFK-2/FBPase-2 content, which was found to be the case (Fig.1 and Table 1). As to the L-PK activity of diabetic rats it was also normalized by vanadate treatment (Table 1 ).

To determine whether the increase in liver PFK2/FBPase-2 content observed with vanadate treatment was due to an increase in PFK-2/FBPase-2 mRNA levels, dot blot (not shown) and Northern blot (Fig. 2,3) hybridizations were performed with total hepatic RNA obtained from the rats of the different experimental groups. $\beta$-Actin mRNA of each sample was also measured because it is a standard reference for the amount of mRNA present $[20,31]$. However, we found (not shown) that insulin treatment increased significantly the levels of $\beta$-actin mRNA, in keeping with an earlier report [32]. This made it impossible to use $\beta$-actin mRNA as an internal control. We therefore hybridized liver RNA from all the experimental groups with a cDNA probe specific for L-PK mRNA. Indeed, L-PK mRNA concentration decreases in diabetes, and increases following insulin administration 
Table 1. Blood glucose, L-PK, and PFK-2 activity and content in experimental groups

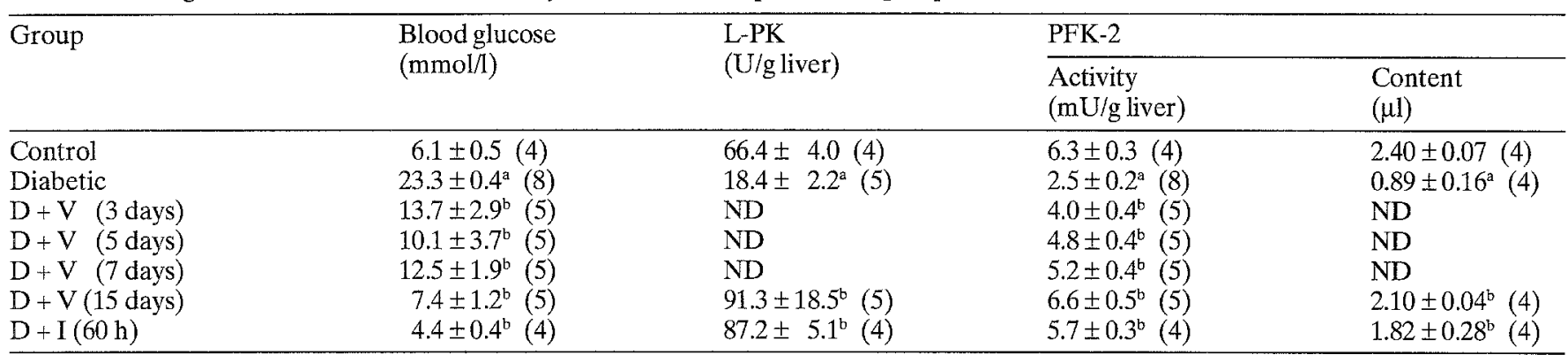

Results are expressed as mean \pm SEM for the number of animals in parentheses. ND, not determined. ${ }^{\mathrm{a}} p<0.05 \mathrm{vs}$ control, ${ }^{\mathrm{b}} p<0.05$ vs diabetic. L-PK, L-type pyruvate kinase; PFK-2, 6-phosphofructo- 2-kinase; V, vanadate; I, insulin. Control and diabetic (D) animals were killed at the same time as the $\mathrm{D}+\mathrm{V}$ (15 days) animals
$[32,33]$. Moreover, vanadate can mimic insulin by increasing L-PK mRNA in cultured hepatocytes [15]. As expected, L-PK mRNA level was reduced to $15 \%$ of the control value in the liver of diabetic rats. Both insulin and vanadate increased the content of mRNA for L-PK in diabetic rat liver, but to a different extent (Fig. 4). Insulin administration for $60 \mathrm{~h}$ raised L-PK mRNA three-fold above control values, while vanadate treatment during 2 weeks normalized L-PK mRNA content. Based on these results, we inferred that our methodology was appropriate to assess the effect of vanadate on PFK2/FBPase-2 mRNA.

Northern blot analysis (Fig.2) showed that PFK2/FBPase-2 mRNA has the length $(2.1 \mathrm{~kb})$ expected for the liver isozyme [28]. Data in Figures 2 and 3 show that the hepatic PFK-2/FBPase-2 mRNA was significantly decreased by diabetes compared with control levels. This is at odds with previous results in which no change was seen

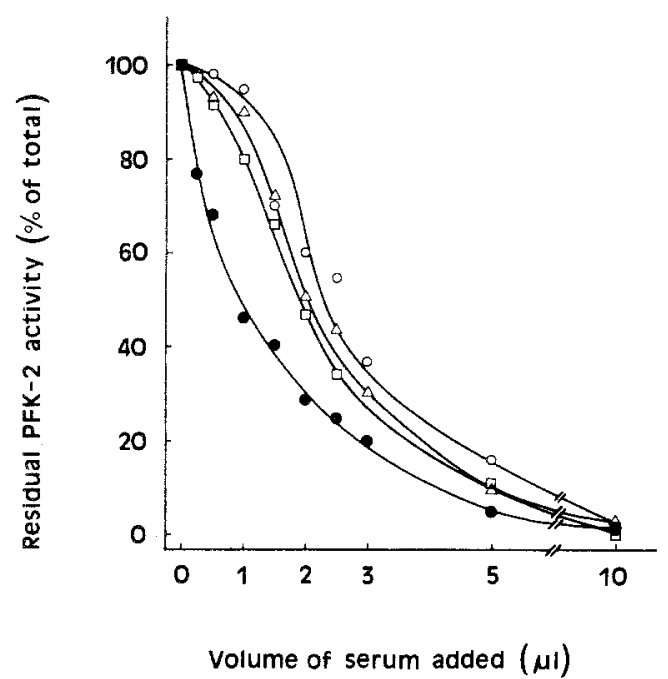

Fig. 1. Immunotitration of liver PFK-2. The enzyme activity was measured at $\mathrm{pH} 8.5$ after immunoprecipitation. All incubations contained $1.5 \mathrm{mg}$ of cytosolic protein/ml, protein A-Sepharose, and different volumes of BCL-2 antiserum. Total 6-phosphofructo 2-kinase (PFK-2) was $66 \mu \mathrm{U} / \mathrm{mg}$ protein in the control rat $(\mathrm{O}), 15 \mu \mathrm{U} / \mathrm{mg}$ protein in the diabetic rat $(\bullet), 55 \mu \mathrm{U} / \mathrm{mg}$ protein in the diabetic rat treated with vanadate for 15 days $(\Delta)$ and $59 \mu \mathrm{U} / \mathrm{mg}$ protein in the diabetic rat treated with insulin for $60 \mathrm{~h}(\square)$. Each curve corresponds to one representative animal (i.e., with the values closest to its group mean) from each experimental group
$[20,21]$. This discrepancy could be due to the smaller number of animals and the resulting large variability of the values [21], or to the fact that diabetes was induced by alloxan instead of streptozotocin and therefore perhaps less severe [20]. Insulin administration for $60 \mathrm{~h}$ resulted in an increase of the PFK-2/FBPase-2 mRNA content above control values (Fig.3). This effect was less than that observed [21] after $48 \mathrm{~h}$ of insulin treatment as if the amount of PFK-2/FBPase-2 mRNA would begin to decline toward the control value, as it did after $96 \mathrm{~h}$ of feeding [21]. Compared to insulin administration, vanadate treatment of diabetic animals produced a slow and progressive increase of PFK-2/FBPase-2 mRNA content, which reached a normal value after 15 days of treatment (Figs. 2, 3).

\section{Discussion}

The results reported in this paper show that oral vanadate treatment of streptozotocin-diabetic rats leads to a recovery of glycaemia and of hepatic Fru-2,6-P2 concentration, as well as PFK-2 and L-PK activities. PFK-2 immunotitration indicated that changes in PFK-2 activity during diabetes and upon insulin or vanadate administration reflect changes in the amount of enzyme. This interpretation is in line with the observation that vanadate and insulin induce the synthesis of PFK-2/FBPase-2 enzyme in cultured rat hepatocytes [16]. L-PK activity of diabetic rats was also normalized by vanadate treatment.

The oral treatment of diabetic animals with vanadate for 15 days restores PFK-2/FBPase- 2 and L-PK mRNAs levels. The time-course and the effectiveness of vanadate treatment were different than those of insulin. Vanadate produced a slow and progressive increase of PFK2/FBPase-2 mRNA but did not reach the values obtained after insulin administration. These differences could probably be due to the different administration route and mechanism of action of vanadate.

There is a lag period of at least $6 \mathrm{~h}$ between injection of insulin and the increase in PFK-2/FBPase-2 [20] and L-PK [33] mRNAs. Noguchi et al. [33] have suggested that insulin may increase transcription of the L-PK gene by stimulating the synthesis of some unknown protein. Recently, Miralpeix et al. [15] have shown that vanadate mimics insulin action on L-PK and glucokinase transcription and, similar to 


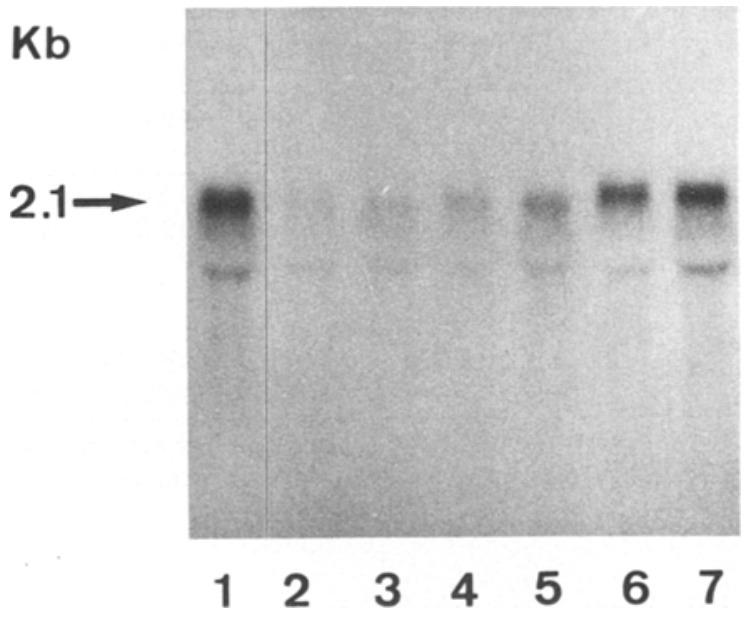

Fig.2. Effect of diabetes and of vanadate or insulin administration on liver 6-phosphofructo 2-kinase/fructose 2,6-bisphosphatase (PFK-2/FBPase-2) mRNA. Autoradiogram of a Northern blot of total liver RNA $(20 \mu \mathrm{g})$ from rats as follows: control (lane 1), diabetic (lane 2), diabetic + vanadate 3 days (lane 3 ), diabetic + vanadate 5 days (lane 4 ), diabetic + vanadate 7 days (lane 5), diabetic + vanadate 15 days (lane 6 ), and diabetic + insulin $60 \mathrm{~h}$ (lane 7). The arrow points to PFK-2/FBPase- 2 mRNA. kb, kilobase

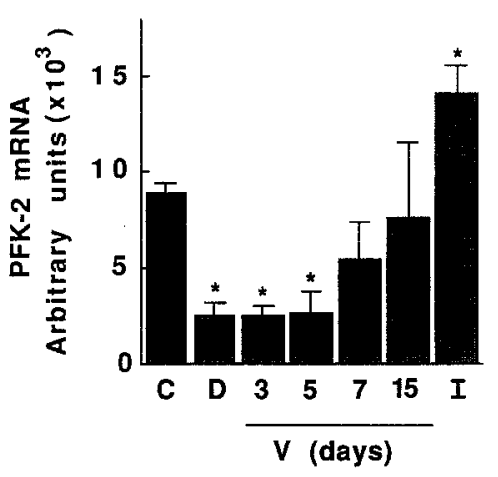

Fig. 3. Northern blot analysis of liver 6-phosphofructo 2-kinase (PFK-2) fructose 2,6-bisphosphatase mRNA. Total liver RNA from control rats $(\mathrm{C}, n=4)$, diabetic rats $(\mathrm{D}, n=8)$, diabetic rats treated with vanadate (V) for 3 days (V3, $n=5$ ), 5 days (V $5, n=5), 7$ days $(\mathrm{V} 7, n=5)$ or 15 days (V15, $n=5)$ and diabetic rats treated with insulin $(\mathbf{I}, n=4)$ was electrophoresed and transferred to a nylon membrane. The relative amounts of mRNA were quantitated using a densitometer. The results are expressed in arbitrary units as means \pm SEM for the specified number of rats indicated. $* p<0.05$ vs control rats

insulin [34], vanadate cannot increase the L-type PK mRNA content in the absence of glucose. This indicates that neither vanadate nor insulin has a direct role on transcription of the L-type PK gene by itself, since glucose is required for its mechanism of action. The intracellular signalling mechanism used by insulin to control PFK2/FBPase-2 mRNA is not known. Cifuentes et al. [35] have shown that insulin increases the content but does not affect the half-life of PFK-2/FBPase-2 mRNA in FTO2B hepatoma cells and that the increase in PFK-2/FBPase-2 mRNA is blocked by an inhibitor of RNA synthesis, suggesting that the effect of insulin is mediated by enhancement of PFK-2 gene transcription, that is dependent, as is L-PK [15,34], on the presence of glucose.
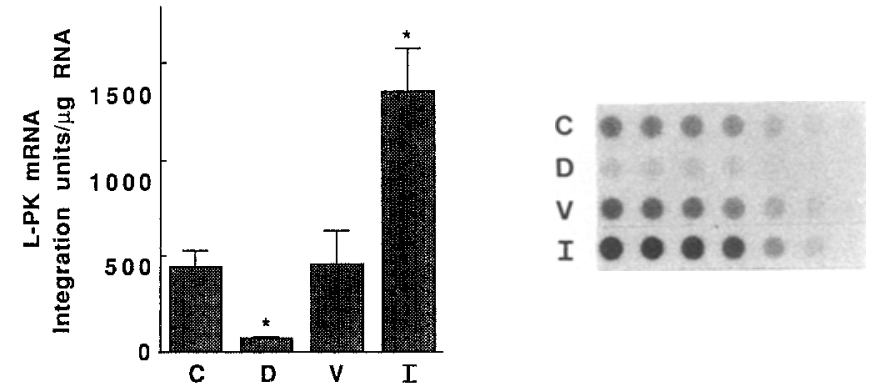

Fig.4. Dot blot analysis of L-type pyruvate kinase (L-PK) mRNA. Total liver RNA from control rats $(\mathrm{C}, n=4)$, diabetic rats $(\mathrm{D}, n=$ 5), diabetic rats treated with vanadate for 15 days $(\mathrm{V}, n=5)$ or with insulin ( $\mathrm{I}, n=4)$ was spotted onto nitrocellulose membranes in different quantities (from left to right, 20, 15, 12.5, 10, 5, 2.5 and $1 \mu \mathrm{g}$ ). The filters were hybridized with the L-PK cDNA probe. Autoradiograms of the filters were scanned with a densitometer. A representative experiment is shown at the right. For each RNA sample, the slope of the linear relationship between $\mu \mathrm{g}$ RNA spotted and integration units (e.g. integration units/ $\mu$ g RNA) was calculated (for all samples, $r^{2}<0.98$ ). The chart on the left shows the mean and SEM of the slopes for each group. ${ }^{*} p<0.05$ vs control rats

Insulin stimulates the expression of several genes including those encoding glyceraldehyde-3-phosphate dehydrogenase, C-Fos, gene 33 product and $\alpha$-amylase [36]. In contrast, insulin inhibits the expression the phosphoenolpyruvate carboxykinase, adipsin and growth hormone genes [36]. Similarly to insulin, vanadate can stimulate the expression of C-Fos [37], $\alpha$-amylase [38], glucokinase and L-PK in hepatocyte cultures [15], and PFK-2 and L-PK in diabetic rat liver as shown here. Vanadate can also inhibit the expression of phosphoenolpyruvate carboxykinase [39]. The similarity of actions of insulin and vanadate suggest that both agents could act via a common pathway. The exact site of action of vanadate remains uncertain. Considerable evidence suggests that insulin-receptor kinase activity plays an essential role in at least some of the intracellular actions of insulin [40]. Accordingly, it has been proposed that vanadate may exert insulin-mimetic effects by maintaining insulin receptor and other endogenous proteins in an appropriate state of phosphorylation as a result of activation of the insulin receptor kinase $[3,41]$ and/or an inhibition of phosphotyrosine phosphatases [42]. However, the lack of effect of vanadate on the level of tyrosine phosphorylation of $\beta$-insulin receptor found by several authors [14, 43-46], and the fact that vanadate stimulates glucose transport in adipocytes that had been treated with trypsin or insulin and Tris to decrease insulin-receptor concentration [4] suggest that its primary action may be at a step distal to the insulin receptor.

In conclusion, our results show that vanadate can also mimic some insulin actions on gene expression, explaining the recovery of the diabetic animals after oral vanadate treatment [10].

Acknowledgements. We are indebted to Drs A.Kahn and M.W.Kirschner for providing the L-type pyruvate kinase and $\beta$-actin cDNA probes, respectively. We thank M. Sust for statistical advice. We also thank Ms. I. Antoine for excellent technical assis- 
tance. This project has been supported by Spanish "Dirección General de Investigación Científica y Técnica" (PM89-0049) and by the Belgian State Prime Minister's Office of Science Policy Programming (Incentive Program in Life Sciences 88/93-122 Grant 20).

\section{References}

1. Shechter Y, Karlish SJD (1980) Insulin-like stimulation of glucose oxidation in rat adipocytes by vanadyl (IV) ions. Nature 284: 556-558

2. Dubyak GR, Kleinzeller A (1980) The insulin-mimetic effects of vanadate in isolated rat adipocytes. J Biol Chem 256: 5306-5312

3. Tamura S, Brown TA, Whipple JH et al. (1984) A novel mechanism for the insulin-like effect of vanadate on glycogen synthase in rat adipocytes. J Biol Chem 259: 6650-6658

4. Green A (1986) The insulin-like effect of sodium vanadate on adipocyte glucose transport is mediated at a post-insulin-receptor level. Biochem J 238: $663-669$

5. Clark AS, Fagan JM, Mitch WE (1985) Selectivity of the insulinlike actions of vanadate on glucose and protein metabolism in skeletal muscle. Biochem J 232: 273-276

6. Tolman EL, Barris E, Burns M, Pansini A, Partridge R (1979) Effects of vanadium on glucose metabolism in vitro. Life Sci 25: 1159-1164

7. Miralpeix M, Gil J, Rosa JL, Carreras J, Bartrons R (1989) Vanadate counteracts glucagon effects in isolated rat hepatocytes. Life Sci 44: 1491-1497

8. Heyliger CE, Tahiliani AG, McNeill JH (1985) Effect of vanadate on elevated blood glucose and depressed cardiac performance of diabetic rats. Science 227: 1474-1477

9. Meyerovitch J, Farfel Z, Sack J, Shechter Y (1987) Oral administration of vanadate normalizes blood glucose levels in streptozotocin-treated rats. J Biol Chem 262: 6658-6662

10. Gil J, Miralpeix M, Carreras J, Bartrons R (1988) Insulin-like effects of vanadate on glucokinase activity and fructose 2,6-bisphosphate levels in the liver of diabetic rats. J Biol Chem 263: 1868-1871

11. Rossetti L, Laughlin MR (1989) Correction of chronic hyperglycemia with vanadate, but not with phlorizin, normalizes in vivo glycogen repletion and in vitro glycogen synthase activity in diabetic skeletal muscle. J Clin Invest 84: 892-899

12. Bollen M, Miralpeix M, Ventura F, Toth B, Bartrons R, Stalmans W (1990) Oral administration of vanadate to streptozotocindiabetic rats restores the glucose-induced activation of liver glycogen synthase. Biochem J 267: 269-271

13. Challis RAJ, Leighton B, Lozeman FJ, Budohoski L, Newsholme EA (1987) Effects of chronic administration of vanadate to the rat on the sensitivity of glycolysis and glycogen synthesis in skeletal muscle to insulin. Biochem Pharmacol 36:357-361

14. Blondel O, Simon J, Chevalier B, Portha B (1990) Impaired insulin action but normal insulin receptor activity in diabetic rat liver: effect of vanadate. Am J Physiol 258: 459-467

15. Miralpeix M, Decaux JF, Kahn A, Bartrons R (1991) Vanadate induction of L-type pyruvate kinase mRNA in adult rat hepatocytes in primary culture. Diabetes 40: 462-464

16. Miralpeix M, Katz NR, Bartrons R (1990) Effects of vanadate on 6-phosphofructo-2-kinase activity and fructose 2,6-bisphosphate levels in cultured rat hepatocytes. Cell Biochem Funct 8: 237-241

17. Van Schaftingen E (1987) Fructose 2,6-bisphosphate. Adv Enzymol 59: 315-395

18. Hue L, Rider MH (1987) Role of fructose 2,6-bisphosphate in the control of glycolysis in mammalian tissues. Biochem J 245: 313324

19. Pilkis SJ, El-Maghrabi MR (1988) Hormonal regulation of hepatic gluconeogenesis and glycolysis. Ann Rev Biochem 57: 755783

20. Crepin KM, Darville MI, Hue L, Rousseau GG (1988) Starvation or diabetes decreases the content but not the mRNA of 6-phosphofructo-2-kinase in rat liver. FEBS Lett 227: 136-140
21. Colosia AD, Marker AJ, Lange AJ et al. (1988) Induction of rat liver 6-phosphofructo-2-kinase/fructose 2,6-bisophosphatase mRNA by refeeding and insulin. J Biol Chem 263:18669-18677

22. Bartrons R, Hue L, Van Schaftingen E, Hers HG (1983) Hormonal control of fructose 2,6-bisphosphate concentration in isolated rat hepatocytes. Biochem J 214: 829-837

23. Felíu JE, Hue L, Hers HG (1983) Regulation in vitro and in vivo of adenosine $3^{\prime}: 5^{\prime}$-monophosphate-dependent inactivation of rat liver pyruvate kinase type L. Eur J Biochem 81: 609-617

24. Kunst A, Draeger B, Ziegenhorn J (1984) UV-methods with hexokinase and glucose-6-phosphate dehydrogenase. In: Bergmeyer HU (ed) Methods of enzymatic analysis, Vol. VI. Verlag Chemie, Weinheim, pp 163-175

25. Bradford M (1976) A rapid and sensitive method for the quantitation of microgram quantities of protein utilizing the principle of protein-dye binding. Anal Biochem 72:248-254

26. Raymondjean M, Kneip B, Schapira G (1983) Preparation and characterization of mRNAs from rat heart muscle. Biochimie 65: 65-70

27. Chirgwin JW, Przybyla AE, MacDonald RJ, Rutter WJ (1979) Isolation of biologically active ribonucleic acid from sources enriched in ribonuclease. Biochemistry 18: 5294-5299

28. Crepin KM, Darville MI, Hue L, Rousseau GG (1989) Characterization of distinct mRNAs coding for putative isozymes of 6-phosphofructo-2-kinase/fructose 2,6-bisphosphatase. Eur J Biochem 183: 433-440

29. Noguchi $T$, Inoue $H$, Tanaka $T$ (1982) Regulation of rat liver L-type pyruvate kinase mRNA by insulin and by fructose. Eur J Biochem 128: 583-588

30. Gil J, Carreras J, Bartrons R (1986) Effects of diabetes on fructose 2,6-bisphosphate, glucose 1,6-bisphosphate and 6-phosphofructo-2-kinase in rat liver. Biochem Biophys Res Commun 136: 498-503

31. Wade DP, Knight BL, Soutar AK (1989) Regulation of low-density-lipoprotein-receptor mRNA by insulin in human hepatoma Hep G2 cells. Eur J Biochem 181: 727-731

32. Chang E, Perlman AJ (1988) Angiotensinogen mRNA. J Biol Chem 263: 5480-5484

33. Noguchi T, Inoue H, Tanaka T (1985) Transcriptional and posttranscriptional regulation of L-type pyruvate kinase in diabetic rat liver by insulin and dietary fructose. J Biol Chem 260: 1439314397

34. Decaux JF, Antoine B, Kahn A (1989) Regulation of the expression of the L-type pyruvate kinase gene in adult rat hepatocytes in primary culture. J Biol Chem 264: 11 584-11590

35. Cifuentes ME, Espinet C, Lange AJ, Pilkis SJ, Hod Y (1991) Hormonal control of 6-phosphofructo-2-kinase/fructose 2,6-bisphosphatase gene expression in rat hepatoma cells. J Biol Chem 266:1557-1563

36. O'Brien RM, Lucas PC, Forest CD, Magnuson MA, Granner DK (1990) Identification of a sequence in the PEPCK gene that mediates a negative effect of insulin on transcription. Science 249:533-536

37. Wice B, Milbrandt J, Glaser L (1987) Control of muscle differentiation in $\mathrm{BC} 3 \mathrm{H} 1$ cells by fibroblast growth factor and vanadate. J Biol Chem 262:1810-1817

38. Johnson TM, Meisler MH, Bennett MI, Willsky GR (1990) Vanadate induction of pancreatic amylase $m R N A$ in diabetic rats. Diabetes 39: 757-759

39. Bosch F, Hatzoglou M, Park EA, Hanson RW (1990) Vanadate inhibits expression of the gene for phosphoenolpyruvate carboxylkinase (GTP) in rat hepatoma cells. J Biol Chem 265: $13677-$ 13682

40. McClain DA, Maegawa H, Lee J, Dull TJ, Ullrich A, Olefsky JM (1987) A mutant insulin receptor with defective tyrosine kinase displays no biological activity and does not undergo endocytosis. J Biol Chem 262: 14663-14671

41. Gherzi R, Caratti C, Andraghetti G et al. (1988) Direct modulation of insulin receptor protein tyrosine kinase by vanadate and anti-insulin receptor monoclonal antibodies. Biochem Biophys Res Commun 152: 1474-1480 
42. Swarup G, Speeg KV Jr Cohen S, Garbers DL (1982) Phosphotyrosyl-protein phosphatase of TCRC-2 cells. J Biol Chem 257: 7298-7301

43. Strout HV, Vicario PP, Superstein R, Slater EE (1989) The insulin-mimetic effect of vanadate is not correlated with insulin receptor tyrosine kinase activity nor phosphorylation in mouse diaphragm in vivo. Endocrinology 124: 1918-1924

44. Mooney RA, Bordwell KL, Luhowskyi S, Casnellie JE (1989) The insulin-like effect of vanadate on lipolysis in rat adipocytes is not accompanied by an insulin-like effect on tyrosine phosphorylation. Endocrinology 124: 422-429

45. Meyerovitch J, Rothenberg P, Shechter Y, Bonner-Weir S, Kahn CR (1991) Vanadate normalizes hyperglycemia in two mouse models of non-insulin-dependent diabetes mellitus. J Clin Invest $87: 1286-1294$
46. Verkatesan N, Avidan A, Davidson MB (1991) Antidiabetic action of vanadyl in rats independent of in vivo insulin-receptor kinase activity. Diabetes 40: $492-498$

Received: 5 August 1991

and in revised form: 18 November 1991

Dr. R. Bartrons

Unitat de Bioquímica

Facultat d'Odontologia

Universitat de Barcelona

Zona Universitària de Bellvitge

E-08907 L'Hospitalet

Spain 